\title{
Satisfaction of Family Members with Treatment in Psychosocial Care Services on Alcohol and Other Drugs
}

\author{
Paula Hayasi Pinho ${ }^{1}$, Márcia Aparecida Ferreira de Oliveira ${ }^{2}$, Maria Odete Pereira ${ }^{3}$, Heloísa Garcia Claro ${ }^{2}$, \\ Ricardo Henrique Soares ${ }^{2}$, Rejane Maria Dias de Abreu Gonçalves ${ }^{2}$, and Carlos Alberto da Cruz Sequeira ${ }^{4}$ \\ ${ }^{1}$ Universidade Federal do Recôncavo da Bahia, Santo Antônio de Jesus, BA, Brazil \\ ${ }^{2}$ Escola de Enfermagem, Universidade de São Paulo, SP, Brazil \\ ${ }^{3}$ Escola de Enfermagem, Universidade Federal de Minas Gerais, Belo Horizonte, MG, Brazil \\ ${ }^{4}$ Escola Superior de Enfermagem do Porto, Porto, Portugal
}

\begin{abstract}
Objective: To assess the satisfaction of family members who had relatives in Psychosocial Care Services on Alcohol and Other Drugs (CAPSad) and the variables associated with the score of satisfaction.

Method: Evaluative, cross-sectional, descriptive, and exploratory research. Data collection was performed with the SATIS-BR instrument, which had been validated for use in Brazil, and sampling was performed by simple randomization, according to a pilot study. The Ethics Research Committee (Protocol 1,001/2011) approved this study. Independent variables included socioeconomic characteristics about the participation of the person at CAPSad and the mean global score of Scale of Perceived Change (SPC); the dependent variable was overall satisfaction. Regression testing was performed using the method of ordinary least squares.
\end{abstract}

Results: In the multivariate analysis, the overall score variables of SPC and family members monitoring to Psychosocial Care Services were positively correlated with overall satisfaction $(p \leq .05)$.

Conclusions: The most family members with relatives receiving services from CAPSad were satisfied. Knowledge of the factors correlated with increased satisfaction might enable the construction of action plans aimed to include the family, during the care process, in these services.

Mental disorders and use of psychoactive substances are considered the biggest contemporary challenges to global public health, with high economic, health, and social costs (World Health Organization [WHO], 2014). Alcohol is the most used licit substance in the world and the WHO (2014) estimates that, in $2012,5.1 \%$ of the global burden of diseases and injuries were attributed to alcohol consumption, and 3.3 million people died due to alcohol use. Latin America is a problematic region concerning worldwide provision and consumption of drugs. About 14.3 million people in the world use cocaine and more than half of them (8.6 million) live in Latin America (Organización Panamericana de la Salud [OPS], 2009). In addition, 162 million people in the world use cannabis and around $23.2 \%$ (37.6 million) of them are located in Latin America (OPS, 2009; United Nations Office on Drugs and Crime [UNODC], 2016). It has also been estimated that about 29 million people are considered problematic users - that is to say, those who are suffering from use-related disorders (UNODC, 2016). In 2011, Bloom et al. estimated that global costs due to mental illnesses throughout the twenty subsequent years might rise to 16,000 million dollars.

In the mental healthcare arena, the Brazilian Psychiatric Reform is known for its implementation of extra-hospital devices in its assistance dimension, with emphasis on Psychosocial Care Services (CAPS, acronym from Centro de Atenção Psicossocial). This movement is enabling a gradual change from hospital-centered care, which is focused on the psychiatric hospital, to a focus on the community, with care centered on users and on their needs, termed psychosocial care (Costa-Rosa, 2000).

With regard to psychoactive substance consumption, the main healthcare strategy in public health services in Brazil is the Psychosocial Care Service on Alcohol and on Other Drugs (CAPSad, acronym from Centro de Atenção Psicossocial Álcool e Drogas), which uses harm reduction as a tool of health prevention and users psychosocial rehabilitation. CAPSad offers daily treatment developed by 
a multiprofessional team. There is not a defined treatment period. The duration of treatment is related to the singular therapeutic project, built jointly by the treatment team and the client, in order to spur the client's integration into the social and family environment, as well as to support the client in the search for autonomy (Ministério da Saúde, 2002).

CAPSad offers the following types of care: individual (medical, psychotherapeutic); group (psychotherapeutic activities, social support); therapeutic workshops; home visits; family care; community activities and family and social integration; right to daily meal; and detoxification (Ministério da Saúde, 2002).

Evaluation is a necessary dimension of public policies, because it is essential to show the public what programs develop from those policies, what their aim is, and how they work. Therefore, CAPS should undergo evaluative processes in order to measure the quality of healthcare provided in institutional spaces (Kantorski et al., 2009) to help us visualize the program's potentialities, as well as understand the fragilities in the healthcare of the population receiving the service.

Evaluating any health activity means comparing what is seen in practice with what is considered the best possible intervention-in other words, comparing what has been routinely done with what should have been done (Ministério da Saúde, 2007).

In evaluating the quality of mental healthcare, analysis of coverage extension, numbers of consultations, hospitalizations, and laboratory procedures does not provide an adequate picture. The objective and material aspects of care, more than in other healthcare arenas, must be approached with consideration for the intersubjectivity of the relations between service users, family members, and treatment professionals, which increases the difficulties already inherent in evaluating quality of care (Furtado \& Campos, 2008).

The World Health Organization (WHO, 2001) recommends evaluations of mental healthcare service that consider the perspective of the client, the client's family members, and the treatment professionals. Increasingly, the satisfaction of those directly involved in the care process has been used as a measure of service evaluation. The present study focuses on the satisfaction of family members with regard to the services clients received and the care results, based on the clients' changes observed by their family members.

Thus, satisfaction evaluation should be considered one of the indicators of treatment result (Bandeira, Pitta, \& Mercier, 2000). This refers to an individual's subjective perception regarding whether his/her needs were met, based on whether expectations for the treatment were or were not achieved (Esperidião \& Trad, 2005).

Given that, in psychosocial care, the care aim of CAPSad teams also includes the family unit in its entire complexity, the family must also have their needs met by mental health community services.

During the care process, it is essential to understand family as a protagonist in treatment, recovery, and process of psychosocial rehabilitation. There is empirical knowledge acquired by caregiver family members, gained in the daily care act of "doing," that must be valued by professionals (Ribeiro, Coimbra, \& Borges, 2012).

Thus, when family members receive proper support and guidance, they can share their difficulties and problems, which also helps them in demonstrating their commitment to the care of the client (Cavalheri, 2010).

The need for more inclusion of family members in the therapeutic plan and institutional evaluative process is seen in the daily of mental health community services (Perreault, Rousseau, Provencher, Roberts, \& Milton, 2012). The evaluation done by family members enables the reorganization and readjustment of care to the needs of clients and their families (Kantorski et al., 2012).

Studies considering the family members' perspectives in the evaluation of mental health services are rare (Bandeira et al., 2011b). Thus, the present study aimed at evaluating family members' satisfaction with the treatment available at CAPSad and the variables associated with this satisfaction.

\section{Method}

This is a cross-sectional evaluation research. To test the instruments and to calculate sampling, the authors conducted a pilot study. The pilot allowed better planning of the data collection of the results presented in this paper. Procedures are described below.

\section{Data Collection Procedures}

The present study is part of a project to evaluate CAPSad from the viewpoint of treatment professionals, clients, and family members of clients. For the sample of family members, the following was done:

(1) A sample of clients that represented the population was calculated using pilot study data. This was a simple randomized sample that used domains of the Family Members' Satisfaction Scale, measuring satisfaction with the mental health service (SATIS-BR) (Bandeira \& Silva, 2012), from the pilot study, with a 5\% significance level, based on the standard error estimation of the dependent variable mean (satisfaction score). The total was 30 clients for each CAPSad.

(2) Each client randomly selected from the 12 (twelve) Psychosocial Care Services on Alcohol and Other Drugs (CAPSad) was contacted by telephone or by home visit. Among the 360 clients we attempted to contact, we successfully contacted 263, 209 (58\% of the total sample) permitted a family member to be interviewed. Of those, 151 family members refused our request to take part in the 
research. Reasons for subject losses included: client denying permission to contact a family member, significant other or close friend (considered by the participant as part of his/her family); family member's refusal to take part in the research; and not being able to successfully contact a subject after a minimum of five contact attempts.

\section{Ethics}

The research was submitted to the Research Ethics Committee of the School of Nursing from Universidade de São Paulo and approved under protocol number 1.001/2011. Interviews were done after signature of the free informed consent. The authors followed all ethical regulations established in the Resolution of the Brazilian National Council of Research Ethics (Ministério da Saúde, 2012).

\section{Data Collection Instruments}

The following items were used for data collection: sociodemographic information; Family Members' Satisfaction Scale regarding the mental health service (SATIS-BR) (Bandeira \& Silva, 2012) and Scale of Perceived Change - Family Members (SPC-Family Members), which were both validated for Brazil (Bandeira et al., 2011a).

SATIS-BR is a 5-point Likert scale in which the higher the score, the higher the satisfaction level of the family member with regard to the service. The scale has three different factors or subscales (Bandeira \& Silva, 2012). The first factor evaluates the service effectiveness in the family member's opinion. Questions like "Do you believe your family member received the type of service (care) you thought he/she needed?" are asked in this factor, and then the family member chooses one of the options in the Likert scale. The second factor evaluates the level of family member's satisfaction regarding the staff's ability and capacity to understand the problem and help the client with his/her needs. This factor has questions like "How much do you think the person who admitted your family member in the service seemed to understand his/her problem?" The third factor evaluates the family member's satisfaction with regard to the measurements performed in the service to ensure privacy and confidentiality of the client's problem (Bandeira \& Silva, 2012). Questions such as "Were you satisfied with the measurements taken to ensure privacy during your contact with the service?" are asked, and one of the options in the Likert scale is chosen. This scale was validated, and the validated study showed good internal consistency (alpha $=0.88$ ) in Brazilian studies, and convergent validity with the SPC scale $(r=0.41 ; p<.001)$ (Bandeira \& Silva, 2012).

The SPC-Family Members is a three-point Likert scale, with higher numbers indicating that family members perceived greater changes to aspects of the clients' lives after they began treatment (Bandeira, Andrade, Costa, \& Silva, 2011a). The scale has 19 items distributed into four subscales. The $19^{\text {th }}$ item refers to the global score of the SPC, in which the family members evaluate their general perception about the treatment results of the client. This scale, when studied with a sample of patients from health services in Brazil, showed internal consistency $($ alpha $=0.85$ ) and test-retest temporal stability $(r=0.96 ; p<.05)$. With regard to the convergent validity, it indicated a significant positive correlation with the scale of related construct of family members' satisfaction with the services $(r=0.41 ; p<.05)$ (Bandeira \& Silva, 2012).

\section{Variables and Strategy of Data Analysis}

The dependent variable was global satisfaction with the health service, which was obtained through calculation of the mean of SATIS-BR (Bandeira \& Silva, 2012) scale. The independent variables were socioeconomic characteristics of the family members, variables regarding the participation of the family member in CAPSad, and mean of SPC global score.

The following independent variables were used in the analysis models:

Relationship to client may have an important role in the interaction of clients with their families, and some close family members, like father, mother or child, may observe the results of CAPSad treatment more easily, which we can assume would affect the perception of satisfaction with service. Therefore, this variable was included in the analysis to verify if there is an association of relationship ties with the obtained satisfaction.

Sociodemographic variables like gender, race, age, marital status, education, work status, income, assets, and number of people living in the domicile were inserted as controls in the model, considering that the social condition and those related to the client's lifestyle could impact one's subjective perception of improvement or satisfaction with the service by acting as confounding variables in the family members' relation with the service satisfaction.

Some variables were added to the model, such as if the family member is the only one taking care of the client, if the family member accompanies the client to treatment, how much time he/she spends to arrive at the CAPSad, if he/she participates in family support groups provided by the service, and if he/she feels overloaded with the client's care. We understood these variables were related to overload of care, which could also affect satisfaction with care received by the client, together with longer time and frequency dedicated to participating in activities through the healthcare service.

Finally, the Perceived Change Scale was inserted as an independent variable to measure if higher scores of perceived change are associated with more satisfaction to family members and if the family members expect that the service will have positive impacts on care, which are observed in larger or smaller intensity in the lives of the CAPSad's users.

The Statistical Package for Social Sciences (SPSS), version 20.0 for Windows, was used to process data. The association between variables was verified by elaborating univariate and multivariate linear regression models through the method of ordinary least squares (Baldi \& Moore, 2014). 
The hypothesis of normality was verified through mean and median closeness of variables, and through Kernel's density estimation graphic (Baldi \& Moore, 2014).

Firstly, a univariate analysis was conducted, and variables with $p \leq .3$ were included in the multiple model. Then, multiple analysis was performed based on the selected variables after the univariate analysis (variables with $p \leq .3$ ). Literature suggests a cut point between .15 and .2. We chose a more conservative cut point to avoid the exclusion of variables that would be significant in the multiple model of the univariate analysis.

The variables were introduced individually in the univariate models, one at a time. For the categorical variables, we chose to insert in the multiple model any variables in which $p$ value was lower than .3 in one or more categories, instead of using the overall $p$ value for the categorical variable, considering that again a more conservative approach would prevent the exclusion of variables in the univariate model phase that would be significant in the final model.

The standard errors were strong to heteroscedasticity, according to the method proposed by White (1980).

For the multicollinearity test, the variance inflation factor was verified for each variable in the final multiple model. According to literature, values lower than 10 do not consider concerns with multicollinearity between the variables (Chatterjee \& Hadi, 2012).

\section{Results}

Among the participating family members/friends, $83.7 \%$ were female, $57.4 \%$ had white ethnicity, $45.9 \%$ were married or had a companion, and the mean age was 53 years old. With regard to the relationship to client, $42.6 \%$ were mothers, $19.6 \%$ were siblings, and $18.2 \%$ were spouses of the clients.

As to the educational level, $24.9 \%$ of the family members/friends had not concluded elementary school, and $23.9 \%$ had completed high school.

In the sample including the studied family members, the mean of residents in the household was four, and $72.7 \%$ had individual household income of two minimum wages at maximum.

With regard to care, $58.9 \%$ of the family members/friends were the only ones who took care of the client, and $50.7 \%$ felt overloaded.

Concerning satisfaction with CAPSad, we calculated the mean of factors that form the SATIS-BR scale, and it was seen that most of the means were close to 5 points, which is the highest satisfaction level with the visited service, as seen in Table 1.
For the factors of SATIS-BR and overall scales, mean and median values remained close, resulting in normality of data distribution interpretation.

Kernel density graphic for the SATIS-BR scale showed an almost normal distribution (Figure 1); a light displacement to the right demonstrates the population's tendency to higher levels of satisfaction.

In Table 2, we analyzed the results of family members' sociodemographic characteristics, the family members' participation at CAPSad, and SPC-Family Members overall scores regarding family members' satisfaction with CAPSad. These results of the univariate models and categories that compose the independent variables of the study were observed with regard to Model 2, mainly, and the assets category refers to the amount of assets the family declares having.

The variables included in the univariate models were relationship to client; gender; color/race; age; marital status; educational level; paid work; individual income; family income; number of residents; sole caretaker status; family assets; frequency in which the family member accompanies the client to CAPSad; time spent traveling to CAPSad; participation in a support/family member group at CAPSad during the last year; overload perception with regard to care of client; overall score of the Perceived Change Scale.

Variables of $p \leq .3$ in the univariate models that were added in the multiple model included: relationship to user; gender; marital status; education; family income; sole caretaker status; assets; if he/she accompanied the family member to CAPSad; time spent traveling to CAPSad; participation in a family group during the last year; overloaded with care of client; and if he/she observed changes in several aspects of the client's life after the beginning of the treatment.

Table 3 presents the results of multiple analysis for the total sample regarding the family members' overall satisfaction.

The following variables with $p \leq .05$ were considered significant in the multiple model: SPC-Family Members overall score and family member's accompaniment to CAPSad.

The associations between variables were positive; therefore, increases in the SPC-Family Members scores were correlated with those in SATIS score, and accompanying the client to CAPSad was associated with the best scores of SATIS-BR scale compared to family members that had never accompanied the client.

The $\mathrm{R}^{2}$ value for this multiple model was $35 \%$ (i.e., this group of variables explained $35 \%$ of the score variation regarding family members' satisfaction). This indicates that the perception the family member has of the serviceobtained changes in several aspects of his/her life after the beginning of the treatment at CAPSad, as well as accompanying the client to CAPSad, were the most important predictors of satisfaction with the mental health service. 
Table 1

Descriptive analysis of the factors in the Brazilian Mental Health Services' Staff Satisfaction (SATIS-BR) scale for the total sample, Brazil (São Paulo), 2014 ( $n=209)$

\begin{tabular}{lcccc}
\hline Variables & Mean & Median & $\begin{array}{c}\text { Standard } \\
\text { deviation }\end{array}$ & Confidence interval (95\%) \\
\hline Factor 1 - SATIS BR & 4.3 & 4.6 & 0.7 & $4.2-4.4$ \\
Factor 2 - SATIS BR & 4.1 & 4.3 & 0.6 & $4.0-4.2$ \\
Factor 3 - SATIS BR & 4.1 & 4.0 & 0.7 & $4.0-4.2$ \\
SATIS BR - overall & 4.2 & 4.3 & 0.6 & $4.1-4.3$ \\
\hline
\end{tabular}

\section{Figure 1}

Kernel density for the SATIS-BR scale

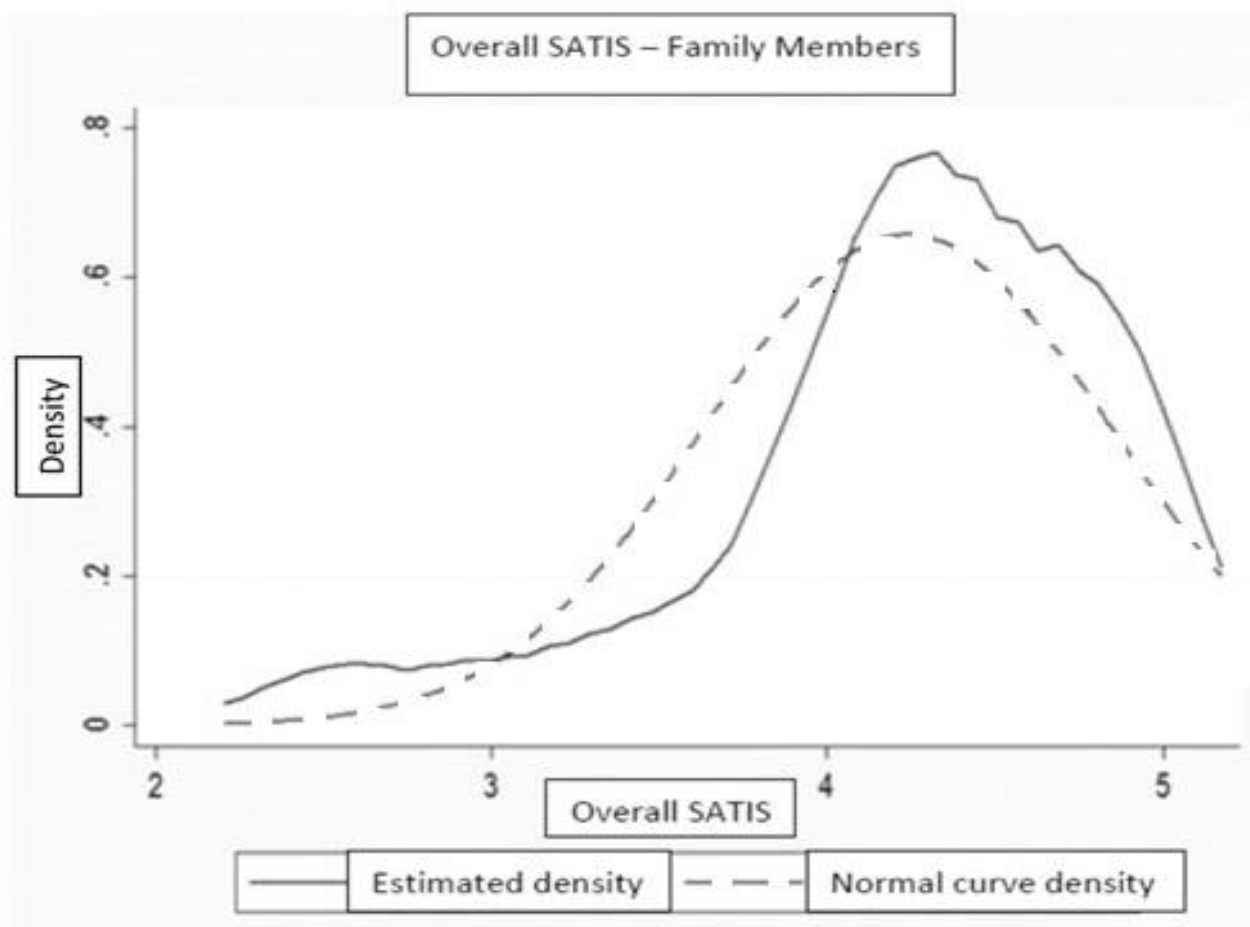

Table 2

Univariate models for sociodemographic characteristics and of participation at Psychosocial Care Services on Alcohol and Other Drugs (CAPSad) and Scale of Perceived Change (SPC-Family Members) overall score of family members from CAPSad family members, according to Brazilian Mental Health Services'Staff Satisfaction (SATIS-BR), São Paulo, SP (n=209)

\begin{tabular}{|c|c|c|c|c|c|}
\hline \multicolumn{2}{|c|}{ Models } & \multirow{2}{*}{$\begin{array}{c}\text { Standard error } \\
0.279\end{array}$} & \multirow{2}{*}{$\begin{array}{c}\text { Standardized } \boldsymbol{\beta} \\
\text { coefficient }\end{array}$} & \multirow{2}{*}{$\begin{array}{c}\boldsymbol{p} \text { value } \\
.392 \\
\end{array}$} & \multirow{2}{*}{$\begin{array}{c}\begin{array}{c}\text { LR test }(\boldsymbol{p} \\
\text { value) }\end{array} \\
4.68(0.46)\end{array}$} \\
\hline Model 1 - & Father & & & & \\
\hline \multirow{4}{*}{$\begin{array}{l}\text { Relationship to the } \\
\text { user (reference - } \\
\text { mother) }\end{array}$} & Brother & 0.115 & -0.011 & .884 & \\
\hline & Spouse & 0.118 & 0.056 & .457 & \\
\hline & Uncle/nephew & 0.145 & -0.014 & .850 & \\
\hline & Child & 0.175 & 0.121 & $.094 *$ & \\
\hline $\begin{array}{l}\text { Model } 2 \text { - Gender } \\
\text { (reference - female) }\end{array}$ & Male & 0.113 & -0.125 & $.070^{*}$ & \\
\hline
\end{tabular}




\begin{tabular}{|c|c|c|c|c|c|}
\hline \multicolumn{2}{|c|}{ Models } & \multirow{2}{*}{$\begin{array}{c}\text { Standard error } \\
0.141\end{array}$} & \multirow{2}{*}{$\begin{array}{c}\begin{array}{c}\text { Standardized } \boldsymbol{\beta} \\
\text { coefficient }\end{array} \\
-0.060\end{array}$} & \multirow{2}{*}{$\begin{array}{c}p \text { value } \\
.405\end{array}$} & \multirow[t]{2}{*}{$\begin{array}{l}\text { LR test ( } p \\
\text { value) }\end{array}$} \\
\hline Model 3 - Ethnicity & Black & & & & \\
\hline & $\begin{array}{c}\text { Dusky skinned/Dark } \\
\text { skinned/ } \\
\text { Mulatto }\end{array}$ & 0.093 & -0.008 & .916 & \\
\hline Model 4-Age & Age & 0.003 & -0.029 & .680 & \\
\hline \multirow{3}{*}{$\begin{array}{l}\text { Model } 5 \text { - } \\
\text { Marital status } \\
\text { (reference - single) }\end{array}$} & With companion & 0.118 & -0.074 & .446 & $2.06(0.56)$ \\
\hline & Divorced & 0.144 & -0.113 & $.201 *$ & \\
\hline & Widowed & 0.138 & -0.102 & $.0262 *$ & \\
\hline \multirow{3}{*}{$\begin{array}{l}\text { Model 6-Education } \\
\text { (reference - } \\
\text { incomplete } \\
\text { elementary school) }\end{array}$} & $\begin{array}{c}\text { Complete Elementary } \\
\text { School/ Incomplete } \\
\text { High School }\end{array}$ & 0.110 & -0.055 & .497 & $4.49(0.21)$ \\
\hline & $\begin{array}{c}\text { Complete High } \\
\text { School/Incomplete } \\
\text { Technical Education }\end{array}$ & 0.112 & 0.036 & .651 & \\
\hline & $\begin{array}{c}\text { Incomplete Higher } \\
\text { Education }\end{array}$ & 0.127 & 0.119 & $.128 *$ & \\
\hline Model 7 - Paid work & Yes & 0.085 & -0.043 & .538 & \\
\hline $\begin{array}{l}\text { Model } 8 \text { - Individual } \\
\text { income (reference - }\end{array}$ & $\begin{array}{l}2 \text { to } 4 \text { minimum } \\
\text { wages }\end{array}$ & 0.107 & 0.017 & .806 & \\
\hline $\begin{array}{l}\text { less than } 2 \text { minimum } \\
\text { wages) }\end{array}$ & $\begin{array}{l}\text { Between } 4 \text { to } 20 \\
\text { minimum wages }\end{array}$ & 0.160 & 0.056 & .426 & \\
\hline $\begin{array}{l}\text { Model } 9 \text { - Family } \\
\text { income (reference - }\end{array}$ & $\begin{array}{l}2 \text { to } 4 \text { minimum } \\
\text { wages }\end{array}$ & 0.095 & 0.141 & $.052 *$ & $6.20(0.05)$ \\
\hline $\begin{array}{l}\text { less than } 2 \text { minimum } \\
\text { wages) }\end{array}$ & $\begin{array}{l}\text { Between } 4 \text { to } 20 \\
\text { minimum wages }\end{array}$ & 0.114 & 0.151 & $.038 *$ & \\
\hline $\begin{array}{l}\text { Model } 10-\text { Number } \\
\text { of people living in } \\
\text { the house }\end{array}$ & Number of people & 0.027 & -0.040 & .570 & \\
\hline $\begin{array}{l}\text { Model } 11- \\
\text { The only one who } \\
\text { takes care of the } \\
\text { client (reference- } \\
\text { No) }\end{array}$ & Yes & 0.085 & 0.085 & $.223^{*}$ & \\
\hline Model 12 - Assets & Number of assets & 0.011 & 0.176 & $.011 *$ & \\
\hline \multirow{4}{*}{$\begin{array}{l}\text { Model } 13- \\
\text { Accompanies the } \\
\text { family member to } \\
\text { CAPSad (reference- } \\
\text { never) }\end{array}$} & Rarely & 0.126 & 0.188 & $.035^{*}$ & $14.11(0.006)$ \\
\hline & Sometimes & 0.123 & 0.175 & $.051 *$ & \\
\hline & Frequently & 0.155 & 0.285 & $.000 *$ & \\
\hline & Always & 0.131 & 0.231 & $.008^{*}$ & \\
\hline \multirow{5}{*}{$\begin{array}{l}\text { Model } 14-\text { Time } \\
\text { spent traveling to } \\
\text { CAPSad (reference - } \\
0 \text { to } 15 \text { minutes) }\end{array}$} & 16 to 30 minutes & 0.130 & 0.149 & $.118^{*}$ & $7.99(0.16)$ \\
\hline & 31 to 45 minutes & 0.137 & 0.006 & .945 & \\
\hline & 46 to 60 minutes & 0.156 & 0.074 & .388 & \\
\hline & $\begin{array}{l}\text { More than } 60 \\
\text { minutes }\end{array}$ & 0.175 & 0.089 & $.271 *$ & \\
\hline & $\begin{array}{l}\text { Does not go to } \\
\text { CAPSad }\end{array}$ & 0.148 & -.072 & .413 & \\
\hline $\begin{array}{l}\text { Model } 15- \\
\text { Participated in a } \\
\text { family group at } \\
\text { CAPSad (reference- } \\
\text { No) }\end{array}$ & Yes & 0.086 & 0.094 & $.176^{*}$ & \\
\hline
\end{tabular}




\begin{tabular}{|c|c|c|c|c|}
\hline Models & Standard error & $\begin{array}{c}\text { Standardized } \beta \\
\text { coefficient }\end{array}$ & $p$ value & $\begin{array}{l}\text { LR test ( } p \\
\text { value) }\end{array}$ \\
\hline $\begin{array}{l}\text { Model } 16-\text { Feels } \\
\text { overloaded with the } \\
\text { client care (reference } \\
- \text { No) }\end{array}$ & 0.083 & -0.137 & $.048 *$ & \\
\hline $\begin{array}{l}\text { Overall SPC-Family } \\
\text { Members }\end{array}$ & 0.085 & 0.448 & $.000 *$ & \\
\hline
\end{tabular}

$* p \leq .3$ : variables to be included in the multiple model.

Source: Psychosocial Care Services on Alcohol and Other Drugs (CAPSad, acronym from Centro de Atenção Psicossocial Álcool e Drogas), São Paulo (SP); 2014.

Table 3

Multiple model for sociodemographic characteristics of participation at Psychosocial Care Services on Alcohol and Other Drugs (CAPSad) and Scale of Perceived Change (SPC-Family Members) overall score of family members from CAPSad family members, according to Brazilian Mental Health Services'Staff Satisfaction (SATIS-BR), São Paulo, SP $(n=209)$

\begin{tabular}{|c|c|c|c|c|}
\hline Multiple model & $\begin{array}{c}\text { Standardized } \beta \\
\text { coefficient }\end{array}$ & Students' $t$ & $p$ value & $\begin{array}{l}\text { LR test }(p \\
\text { value })\end{array}$ \\
\hline (Constant) & 2.101 & 5.951 & $\leq .01^{*}$ & \\
\hline Overall SPC-Family Members & 0.400 & 5.862 & $\leq .01 *$ & \\
\hline $\begin{array}{l}\text { Relationship to client - category of } \\
\text { reference - mother }\end{array}$ & & & & $4.01(0.54)$ \\
\hline Relationship to client - father & 0.020 & 0.287 & .775 & \\
\hline Relationship to client - brother & 0.005 & 0.061 & .952 & \\
\hline Relationship to client- companion & 0.075 & 1.003 & .317 & \\
\hline Relationship to client - nephew/uncle & -0.055 & -0.692 & .490 & \\
\hline Relationship to client - child & 0.077 & 1.039 & .300 & \\
\hline \multicolumn{5}{|l|}{ Gender - category of reference - female } \\
\hline Male gender & -0.127 & -1.725 & .086 & \\
\hline $\begin{array}{l}\text { Marital status - category of reference - } \\
\text { single }\end{array}$ & & & & $1.7(0.64)$ \\
\hline Marital status - with companion & -0.075 & -0.767 & .444 & \\
\hline Marital status - divorced & -0.086 & -1.028 & .305 & \\
\hline Marital status - widowed & -0.017 & -0.182 & .856 & \\
\hline $\begin{array}{l}\text { Education - category of reference - } \\
\text { incomplete elementary school }\end{array}$ & & & & $1.08(0.78)$ \\
\hline $\begin{array}{l}\text { Education - complete elementary school/ } \\
\text { incomplete high school }\end{array}$ & -0.060 & -0.788 & .432 & \\
\hline $\begin{array}{l}\text { Education - complete high school/ } \\
\text { incomplete technical education }\end{array}$ & -0.067 & -0.808 & .420 & \\
\hline Education - incomplete higher education & -0.027 & -0.303 & .762 & \\
\hline $\begin{array}{l}\text { Family income - category of reference - } \\
\text { less than } 2 \text { minimum wages }\end{array}$ & & & & $4.3(0.12)$ \\
\hline Family income -2 to 4 minimum wages & 0.098 & 1.355 & .177 & \\
\hline $\begin{array}{l}\text { Family income - between } 4 \text { to } 20 \text { minimum } \\
\text { wages } \\
\text { Care of client - category of reference - has } \\
\text { help to take care of family member }\end{array}$ & 0.151 & 1.811 & .072 & \\
\hline The only one who took care of the client & 0.106 & 1.485 & .139 & \\
\hline Assets & 0.135 & 1.738 & .084 & \\
\hline $\begin{array}{l}\text { Accompanies the client to CAPSad - } \\
\text { category of reference - never }\end{array}$ & & & & $12.82(0.01 *)$ \\
\hline
\end{tabular}




\begin{tabular}{|c|c|c|c|c|}
\hline Multiple model & $\begin{array}{l}\text { Standardized } \beta \\
\text { coefficient }\end{array}$ & Students' $t$ & $p$ value & $\begin{array}{l}\text { LR test ( } p \\
\quad \text { value) }\end{array}$ \\
\hline Accompanies the client to CAPSad - rarely & 0.338 & 2.269 & $.024 * *$ & \\
\hline $\begin{array}{l}\text { Accompanies the client to CAPSad - } \\
\text { sometimes }\end{array}$ & 0.419 & 2.662 & $.008 *$ & \\
\hline $\begin{array}{l}\text { Accompanies the client to CAPSad - } \\
\text { frequently }\end{array}$ & 0.408 & 3.252 & $.001 *$ & \\
\hline $\begin{array}{l}\text { Accompanies the client to CAPSad - } \\
\text { always }\end{array}$ & 0.415 & 2.850 & $.005 *$ & \\
\hline $\begin{array}{l}\text { Time spent traveling from home to CAPSad } \\
\text { - category of reference }- \text { zero to } 15 \text { minutes }\end{array}$ & & & & $6.37(0.27)$ \\
\hline $\begin{array}{l}\text { Time spent traveling from home to CAPSad } \\
-16 \text { to } 30 \text { minutes }\end{array}$ & 0.086 & 0.946 & .345 & \\
\hline $\begin{array}{l}\text { Time spent traveling from home to CAPSad } \\
-31 \text { to } 45 \text { minutes }\end{array}$ & -0.020 & $\begin{array}{r}-0.222 \\
0.505\end{array}$ & $\begin{array}{r}.825 \\
614\end{array}$ & \\
\hline $\begin{array}{l}\text { Time spent traveling from home to CAPSad } \\
-46 \text { to } 60 \text { minutes }\end{array}$ & 0.042 & 0.505 & .614 & \\
\hline $\begin{array}{l}\text { Time spent traveling from home to CAPSad } \\
\text { - more than } 60 \text { minutes }\end{array}$ & 0.006 & 0.082 & .935 & \\
\hline $\begin{array}{l}\text { Time spent traveling from home to CAPSad } \\
\text { - does not go to the CAPSad } \\
\text { Family groups participation - category of } \\
\text { reference - did not participate in a family } \\
\text { group }\end{array}$ & 0.252 & 1.894 & .060 & \\
\hline Participated in a family group at CAPSad & -0.022 & -0.281 & .779 & \\
\hline \multicolumn{5}{|l|}{$\begin{array}{l}\text { Caregiver burden - category of reference - } \\
\text { does not feel overloaded with care }\end{array}$} \\
\hline Feels overloaded with family member's care & -0.055 & -0.764 & .446 & \\
\hline
\end{tabular}

* Significant if $p \leq .01$; ** significant if $p \leq .05$.

\section{Discussion}

The sociodemographic profile of family members comprised mostly female gender, elementary school education, in a relationship, and feeling overloaded with care provided to the client. These results are in agreement with those found in studies that evaluated family members' satisfaction (Bandeira et al, 2011a; Bandeira et al., 2011b; Bandeira \& Silva, 2012; Baldi \& Moore, 2014; White, 1980; Jardim, Quevedo, Kantorski, Saraiva, \& Silva, 2013).

Considering that all scores for the factors of the satisfaction scale were higher than 4.10 , the family member of the client receiving services presented a moderate to high satisfaction regarding the evaluated aspects.

These results are corroborated by other studies (Bandeira et al, 2011a; Bandeira et al., 2011b; Bandeira \& Silva, 2012; Baldi \& Moore, 2014; White, 1980; Jardim et al., 2013; Santos \& Cardoso, 2014), in which the overall satisfaction was between 4.0 and 4.41 ; factor 1 was between 4.55 and 4,28 ; and the factor 2 was between 3.62 and 4.29 .

The scores found in the present study are confirmed by findings from other research; therefore they confirm the tendency of family members from clients of public mental health services to present moderate to high satisfaction regarding the evaluated aspects of those services (Bandeira et al., 2011b).

One of the hypotheses that contribute to explaining the high level of family member satisfaction with the mental health service can be associated with the relation between educational level and satisfaction with the provided services, in which a lower level of education would reduce the critical capacity to evaluate more objectively their perceptions concerning the service that was provided to them (Esperidião $\&$ Trad, 2005).

Another explanatory hypothesis points out the factor associated with cost of services at CAPSad (services are provided free of fees to clients) that might contribute to the increase of satisfaction (Esperidião \& Trad, 2005).

As a result of the participant observation and interview with clients and family members during data collection, the authors infer that compared to previous treatment experiences in psychiatric hospitals and therapeutic communities with infrastructure and approach exclusively via drug-therapy, the community services where they today receive the care they need positively stand out in their evaluative perception. 
However, biases regarding the high satisfaction of family members can be reduced using multifactor instruments with standardized measures, evaluated psychometric proprieties, and validity of the measured constructs (Bandeira et al., 2011b; Esperidião \& Trad, 2005), such as the SATIS-BR scale that was applied in this study.

Given that the satisfaction evaluation is an indicator of treatment result, we aimed at correlating this measurement socioeconomic variables regarding the family member's participation at CAPSad and the SPC-Family Members overall score.

Results indicate that when a family member notices that changes occurring as a result of treatment in different aspects of a CAPSad client's life, the family member shows more satisfaction with the care service provider.

An international multicenter study carried out in involuntary hospitalization services revealed that when users show some favorable change regarding the disease symptomology at the end of four weeks, the family members show increased satisfaction (Giacco et al., 2012).

In agreement with the findings of this study, other investigations reported that family members' satisfaction increased regarding the service when the clients decreased their problematic behaviors (Perreault, Rousseau, Provencher, Roberts, \& Milton, 2012), and family members of clients with better overall functioning were more satisfied with mental health services (Stengård, Honkonen, Koivisto, \& Salokangas, 2000).

Another important predictive factor in family members' satisfaction refers to accompanying the client to CAPSad, regardless of the intensity of this contact with the servicein other words, the family member who accompanied the client to CAPSad felt more satisfied compared to those who had never accompanied the client.

A possible hypothesis for this finding is that family members who accompany users to the service interact and exchange more information with the treatment team, even if informally; thus they feel like participants in the treatment and as though they are included in the service.

The family member's who participates more of the client's activities on the CAPSad, and not only the "family members' therapeutic group" or "family members' meeting" is associated with his/her higher satisfaction and was also discussed before in other studies (Azevedo \& Miranda, 2010, Perreault et al., 2010). Other possibilities of family members' inclusion in the treatment and service are home visits and spaces or activities to empower them considering their daily demands (Pinho, Hernández, \& Kantorski, 2010).

Authors believe this "informal" service enables more contact of the family member with the CAPSad, although this might bring some obstacles, such as the delay of scheduled daily routines of the staff, when the visits were not previously scheduled. A strategy could be the inclusion of a shift professional during CAPS service periods to be available to respond to spontaneous demands with regard to meeting with family members and making them feel included in the client's treatment.

Many family members would like to have access to other ways of participating in the services, but such access is unavailable because other modes of participation are nonexistent, or because the inefficient infrastructure or inflexible organizational management do not allow for their inclusion (Azevedo \& Miranda, 2010).

Many times, professionals of the health interdisciplinary team have difficulties in including family members in alternative activities at the service, because the technical team is reduced, thus creating work overload. The authors indicate as an alternative the extension of CAPSad service time to 9 p.m., for those still working in the II modality. As to CAPS III, they could have family members' groups on Saturdays, thus allowing that people who work during the week could have the opportunity of participating. This possibility is also valid for mental health CAPS.

Teams must pay attention to the moment when families arrive in order to establish proper care and strengthen bonds. Thus, we must create attention and care services for the family in the client's rehabilitation process, making them also responsible for the client's care and giving visibility to the caregiver's actions (Mielke, Kohlrausch, Olschowsky, \& Schneider, 2010).

Treatment professionals must be aware of the family's difficulties and make themselves available to offer support for tasks and decisions regarding care, seeking to strengthen the relations that can produce health, understanding that the family is part of a social network involved in psychosocial care processes (Pinho et al., 2010).

Family members who seek support and guidance at health services, because they want to find alternatives for care and healthy ways of extending bridges in their relationship to the client in order to improve family living and assume care coresponsibility, need the attention of treatment professionals that are sensitive to the demands of the family member who provides care but also needs care.

Authors consider that this study helps to better understand the relationship between family members and CAPSad staff, their needs and subjectivities. .

This work also contributed to an understanding that family members' satisfaction is an indicator of care quality for clients of the Psychosocial Care Network.

\section{Conclusion}

We verified most family members of users from CAPSad were satisfied. These results might help in the perception of the factors in charge of the highest and lowest rates of family members' satisfaction, as well as the factors correlated with the increase of satisfaction, which might enable the construction of action plans that aim at including the family in the care process of these services. 


\section{Acknowledgements}

The authors would like to acknowledge the support of the Coordination for the Improvement of Higher Education Personnel (CAPES) for the $\mathrm{PhD}$ and postdoctoral scholarships, and financial support.

\section{References}

Azevedo, D. M., \& Miranda, F. A. (2010). Práticas profissionais e tratamento ofertado nos CAPSad do município de Natal-RN: Com a palavra a família. Escola Anna Nery Revista de Enfermagem, 14(1), 5663.

Baldi, B., \& Moore, D. S. (2014). The practice of statistics in the life sciences. New York, NY: W. H. Freeman.

Bandeira, M., Andrade, M. C., Costa, C. S., \& Silva, M. A. (2011a). Percepção dos pacientes sobre o tratamento em serviços de saúde mental: Validação de Escala de Mudança Percebida. Psicologia: Reflexão e Crítica, 24(2), 236-244.

Bandeira, M., Felicio, C. M., \& Cesari, L. (2010). Validação da escala de percepção de mudanças pelos familiares como medida de resultado do tratamento em serviços de saúde mental. Revista Brasileira de Psiquiatria, 32(3), 283-287.

Bandeira, M., Pitta, A. M., \& Mercier, C. (2000). Escala de avaliação da satisfação dos usuários em serviços de saúde mental: SATIS-BR. Jornal Brasileiro de Psiquiatria, 49(8), 293-300.

Bandeira, M., \& Silva, M. A. (2012). Escala de satisfação dos pacientes com os serviços de saúde mental (SATIS-BR): Estudo de validação. Jornal Brasileiro de Psiquiatria, 61(3), 124-132.

Bandeira, M., Silva, M. A., Camilo, C. A., \& Felício, C. M. (2011b). Satisfação de familiares de pacientes psiquiátricos com os serviços de saúde mental e seus fatores associados. Jornal Brasileiro de Psiquiatria, 60(4), 284-293.

Bloom, D. E., Cafiero, E. T., Jané-Llopis, E., AbrahamsGessel, S., Bloom, L. R., Fathima, S., .. . Weinstein, C. (2011). The global economic burden of noncommunicable diseases. Geneva, Switzerland: World Economic Forum.

Cavalheri, S. C. (2010). Transformações do modelo assistencial em saúde mental e seu impacto na família. Revista Brasileira de Enfermagem, 63(1), 51-57.

Chatterjee, S., \& Hadi, A. S. (2012). Regression analysis by example $\left(4^{\text {th }}\right.$ ed.). Hoboken, NJ: Wiley.

Costa-Rosa, A. (2000). O modo psicossocial: Um paradigma das práticas substitutivas ao modo asilar. In P. Amarante (ed.), Ensaios - Subjetividade, saúde mental, sociedade (pp. 141-1468). Rio de Janeiro, Brasil: Fiocruz.

Esperidião, M. A., \& Trad, L. A. (2005). Avaliação de satisfação de usuários. Ciências e Saúde Coletiva, 10(Suppl), 303-312.

Furtado, J. P., \& Campos, R. O. (2008). Participação, produção de conhecimento e pesquisa avaliativa: A inserção de diferentes atores em uma investigação em saúde mental. Cadernos de Saúde Pública, 24(11), 2671-2680.

Giacco, D., Fiorillo, A., Del Vecchio, V., Kallert, T., Onchev, G., Raboch, J., . . . Priebe, S. (2012).

Caregivers' appraisals of patients' involuntary hospital treatment: European multicentre study. British Journal of Psychiatry, 201(6), 486-491.

Jardim, V. M., Quevedo, A. L., Kantorski, L. P., Saraiva, S. S., \& Silva, E. N. (2013). Perfil do familiar de pacientes crônicos em sofrimento psíquico. Ciência, Cuidado e Saúde, 7. Retrieved from: http://periodicos.uem.br/ojs/index.php/CiencCuidSaud e/article/view/20880/pdf

Kantorski, L. P., Jardim, V. R., Delpino, G. B., Lima, L. M., Schwartz, E., \& Heck, R. M. (2012). Perfil dos familiares cuidadores de usuários de centros de atenção psicossocial do sul do Brasil. Revista Gaúcha de Enfermagem, 33(1), 85-92.

Kantorski, L. P., Jardim, V. R., Wetzel, C., Olschowsky, A., Schneider, J. F., Heck, R. M., . . S Saraiva, S. S. (2009). Satisfação dos usuários dos centros de atenção psicossocial da região Sul do Brasil. Revista de Saúde Pública, 43(Suppl 1), 29-35.

Mielke, F. B., Kohlrausch, E., Olschowsky, A., \& Schneider, J. F. (2010). A inclusão da família na atenção psicossocial: Uma reflexão. Revista Eletrônica de Enfermagem, 12(4), 761-765. Retrieved from https://www.fen.ufg.br/fen_revista/v12/n4/v12n4a23.h $\underline{\mathrm{tm}}$

Ministério da Saúde. (2002). Dispõe sobre os Centros de Atenção Psicossocial (Portaria n. 336/GM, de 19 de fevereiro de 2002). Brasília, Brasil: Ministério da Saúde.

Ministério da Saúde. (2007). Programa Nacional de Avaliação de Serviços de Saúde (PNASS). Resultado do processo avaliativo 2004-2006. Brasília, Brasil: Ministério da Saúde.

Ministério da Saúde. (2012). Conselho Nacional de Saúde. Resolução n. 466 de 12 de dezembro de 2012. Brasília, Brasil: Ministério da Saúde.

Organización Panamericana de la Salud. (2009). Epidemiologia del uso de drogas em

América Latina y el Caribe: Um enfoque de la salud pública. Washington. Washington, D.C: Organización Panamericana de la Salud.

Perreault, M., Rousseau, M., Provencher, H., Roberts, S., \& Milton, D. (2012). Predictors of caregiver satisfaction with mental health services. Community Mental Health Journal, 48(2), 232-237.

Pinho, L. B., Hernández, A. M., \& Kantorski, L. P. (2010). Reforma psiquiátrica. Trabalhadores de saúde mental e a "parceria" da família: O discurso do distanciamento. Interface (Botucatu), 14(32), 103 113. Retrieved from http://www.scielo.br/scielo.php?script=sci_arttext\&pi $\mathrm{d}=\mathrm{S} 1414-32832010000100009 \& \operatorname{lng}=\mathrm{en}$

Ribeiro, J. P., Coimbra, V. C., \& Borges, A. M. (2012). Grupos de familiares de um centro de atenção psicossocial: Experiências de seus usuários. Revista de Enfermagem da Universidade Federal de Santa Maria, 2(2), 375-385. Retrieved from 
http://cascavel.ufsm.br/revistas/ojs-

2.2.2/index.php/reufsm/article/view/4582

Santos, A. F., \& Cardoso, C. L. (2014). Familiares

cuidadores de usuários de serviço de saúde mental:

Satisfação com serviço. Estudos de Psicologia (Natal),

19(1), 13-21. Retrieved from

http://www.scielo.br/scielo.php?script=sci_arttext\&pi

$\mathrm{d}=$ S1413-294X2014000100003\&lng=en\&tlng=pt.

10.1590/S1413-294X2014000100003

Stengård, E., Honkonen, T., Koivisto, A. M., \&

Salokangas, R. K. (2000). Satisfaction of caregivers of patients with schizophrenia in Finland. Psychiatric Services, 51(8), 1034-1039.

United Nations Office on Drugs and Crime. (2016). World drug report. Geneva, Switzerland: United Nations.

White, H. (1980). A heteroskedasticity-consistent covariance matrix estimator and a direct test for heteroskedasticity. Econometrica, 48(4), 817-838.

World Health Organization. (2001). The world health report. Mental health: New understanding, new hope. Geneva, Switzerland: World Health Organization.

World Health Organization. (2014). Global status report on alcohol and health. Geneva, Switzerland: World Health Organization. 